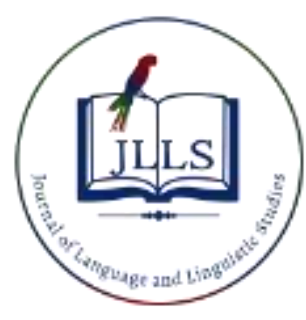

Available online at www.jlls.org

JOURNAL OF LANGUAGE AND LINGUISTIC STUDIES

ISSN: $1305-578 \mathrm{X}$

Journal of Language and Linguistic Studies, 16(2), 626-646; 2020

\title{
Exploring Turkish EFL teachers' perceptions of the factors affecting technology integration: A case study
}

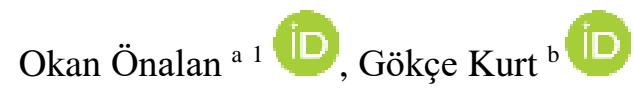 \\ ${ }^{a}$ Independent Researcher, Ankara, Turkey \\ APA Citation: \\ ${ }^{b}$ Marmara University, Istanbul, Turkey
}

Önalan,O., \& Kurt, G. (2020). Exploring Turkish EFL teachers' perceptions of the factors affecting technology integration: A case study. Journal of Language and Linguistic Studies, 16(2), 626-646.

Submission Date: $12 / 05 / 2020$

Acceptance Date:21/05/2020

\begin{abstract}
When technology is integrated into instruction in conjunction with effective teaching practices, it can enrich and enhance teaching and learning processes. With the changes in the nature of education wrought by advances in technology, teachers' key role in the successful integration of technology into the classroom has gained further significance. Therefore, it has become critical to understand the factors affecting teachers' technology integration. The present case study conducted with 70 university-level Turkish EFL teachers focuses on the factors affecting teachers' technology integration practices and specifically explores teachers' knowledge about computer software programs, personal computer-use habits, attitudes toward and self-confidence in integrating computer-based technologies into teaching, and their views about school climate and support. Analysis of the data coming from a questionnaire demonstrates that teachers know well about commonly-used software programs, they have positive attitudes toward using technology in their teaching, they have a high level of self-confidence in integrating technology into their teaching, they enjoy positive school climate among colleagues, but they see limited support from administration especially in terms of technological infrastructure and instructional encouragement. The findings of this study have implications regarding technology integration in the classroom in that teachers need to be provided with ample technology, along with administrative and technical support as well as continuous training specifically designed to address their identified needs in technology use and integration.
\end{abstract}

C 2020 JLLS and the Authors - Published by JLLS.

Keywords: EFL teachers; perceptions; technology integration; attitudes; self-confidence.

\section{Introduction}

For the last several decades, technology integration into the classroom has been at the forefront of education. Technology integration refers to "the effective implementation of educational technology to accomplish intended learning outcomes" (Davies \& West, 2014, p. 6). The use of technology in schools can be categorized into three groups as using technology for instructional preparation, for instructional delivery and as a learning tool (Inan \& Lowther, 2010). Teachers' using technology for instructional

\footnotetext{
${ }^{1}$ Corresponding author. Tel.: +90-312-677-1204

E-mail address: okanonalan@gmail.com
} 
preparation involves the use of technology to prepare classroom activities such as creating teaching materials, writing lesson plans or collaborating with peers. Technology use for instructional delivery mainly refers to teachers' using computers as delivery tools to present new content or to engage students to use computers to do some activities. Using technology as a tool involves students' use of technology as a learning tool to solve problems, create products or communicate and share with others (Inan \& Lowther, 2010; Inan, Lowther, Ross, \& Strahl, 2010).

When technology is integrated in conjunction with effective teaching practices, it can enrich and enhance teaching and learning processes. Thus, teachers play a key role in the successful integration of technology into the classroom and the extent to which students can benefit from technology-enhanced instruction (Kurt, 2010; Teo, 2011). Numerous studies have focused on technology integration in different subject areas and across all grades, from kindergarten to higher education. These studies have demonstrated that actual technology integration is still far from being effectively implemented. Many teachers have appeared to use technology, if at all, in a very limited way, mostly for non-instructional purposes such as completing administrative tasks or using it for communication (e.g., Ertmer, 2005; Ertmer \& Ottenbreit-Leftwich, 2013; Kurt, 2010; Morrison \& Lowther, 2010). Even when technology is used for instructional purposes, its use is limited to using it as a delivery tool, rather than as a learning tool (Inan et al., 2010; Morrison \& Lowther, 2010). In other words, the process of achieving technology integration into classroom teaching is slow and complex and influenced by various factors (Inan \& Lowther, 2010). Therefore, it is important to understand the factors that have an impact on teachers' decisions to reject or adopt technology in their teaching.

\subsection{Literature Review}

\subsubsection{Factors Affecting Teachers' Technology Integration Practices}

A considerable amount of research has been conducted to explore factors that facilitate or act as barriers to teachers' technology integration practices in education (e.g., Ertmer, 1999, 2005; Ertmer \& Ottenbreit-Leftwich, 2010; Hew \& Brush, 2007; Buabeng-Andoh, 2012). An extended list of teacher and school related factors such as teachers' demographic characteristics, beliefs and attitudes, availability of and access to technology and the school culture and support has been identified as significantly affecting technology integration. Among various teacher related variables, beliefs and attitudes have been regarded as the most powerful predictors of teachers' use of technology in the classroom (Ertmer, 2005; Koh \& Chai, 2014; Ottenbreit-Leftwich, Glazewski, Newby, \& Ertmer, 2010; Hermans, Tondeur, Van Braak, \& Valcke, 2008; Sang, Valcke, Van Braak, \& Tondeur, 2010).

Several kinds of teacher beliefs that relate to technology use and integration have been explored in previous studies. For example, teachers' perceived competency or self-efficacy beliefs in technology skills is associated with more frequent technology integration in the classroom $(\mathrm{Li}$, Garza, Keicher, \& Popov, 2018). Sipila's study (2014) presented evidence that teachers with higher technology knowledge used technology more frequently for teaching purposes. Anderson, Groulx and Maninger (2011) found a correlation between self-efficacy beliefs of teachers and their intention to use technology. In his study with 3.729 teachers in Taiwan, Hsu (2010) also found out that teachers with higher perceived efficacy beliefs in technology integration used technology more frequently in their classroom. Similarly, in their study with 1.382 public school teachers, Inan and Lowther (2010) found a direct relationship between teachers' self-efficacy beliefs in using technology and their technology integration practices. Teachers who believed in the positive effects of technology use on students' learning also tended to use technology more frequently. Ertmer, Ottenbreit-Leftwich, Sadik, Sendurur and Sendurur (2012) indicated that teachers' beliefs that related to the importance of technology in supporting students' learning had the biggest impact on their successful technology integration practices. Based on their study with 223 K-12 school teachers in the United States, Hur, Shannon and Wolf (2016) also concluded 
that teachers who believed in the strong value of technology integration tended to have higher use of technology for teaching purposes.

Teacher attitudes have also been discussed as an important factor in the adoption and integration of technology (Hew \& Brush, 2007; Lawrence \& Tar, 2018; Salleh, 2016). Positive attitudes increase teachers' willingness and efforts to integrate technology into their teaching (Hernández-Ramos, Martínez-Abad, Peñalvo, García, \& Rodríguez-Conde, 2014). In their large-scale study, Van Braak, Tondeur and Valcke (2004) created a path model to explain teachers' different types of computer use and found out that teachers' attitudes toward computers in education had a very strong effect on their computer use in the classroom. Likewise, Salleh's study (2016) revealed that teachers' positive attitudes toward technology integration strongly influenced their use of technology.

The school variables discussed in relation to the impact they have on teachers' use of technology include access to technology and receiving adequate technical, training, and administrative support. Among these variables, availability of and access to technology infrastructure has been identified as the crucial and most relevant factor influencing technology integration practices in education (e.g., Hew \& Brush, 2007; Ertmer \& Ottenbreit-Leftwich, 2013; Light \& Pearson, 2013). Effective technology integration depends on the availability and accessibility of technological resources such as hardware, Internet, instructional software and Web 2.0 tools not only for teachers but also for students. In their study with 1.922 teachers from 13 developing countries, Light and Pearson (2013) aimed to investigate how differing degrees of teachers' and students' access to technology influenced teachers' use of technology in the classroom. The findings revealed that providing students with access to technological resources supported teachers' technology use with their students. In other words, teachers whose students had access to technology, integrated more technology-based materials into their teaching. Also, technical support which refers to the assistance provided to the teachers for setting up and maintaining technology hardware and software influences teachers' readiness to integrate technology (Inan \& Lowther, 2010; Makki, O’Neal, Cotton, \& Rikard, 2018). In their study with high school teachers, Gürfidan and Koç (2016) found out that among different school related variables, technical support had the highest effect on teachers' technology use. Likewise, in the studies of Hsu (2010) and Francom (2020), it was concluded that a lack of technical support would impede teachers' technology integration practices in the classroom.

Administrative support as a factor in technology integration involves the leadership actions (Schrum, Galizio, \& Ledesma, 2011). As Schiller (2003) states "without the leadership support, the educational potential of information and communication technology may not be realized" (p. 171). For successful technology implementations, teachers need effective administrators serving as role-models (Murphy \& Gunter, 1997). Administrators can support teachers' successful technology integration by modeling technology use, showing the value they attach to technology integration, encouraging teachers to move beyond traditional teaching and letting teachers be autonomous to take risks (Durff \& Carter, 2019; Sheninger, 2014). It was also suggested by Wong and $\mathrm{Li}$ (2008) that the collaborative culture created by school leaders influences effective technology integration. As Durff and Carter (2019) stated "social connections and cultural landscapes surrounding educators affected when and how teachers implemented technology in their classrooms" (p. 248).

Ertmer, Ottenbreit-Leftwich and York (2006) refer to the factors that positively influence teachers' decisions to adopt technology and facilitate technology integration processes as enablers and discuss them in relation to the barriers to technology integration. Barriers to technology use have been widely studied in the educational literature (e.g., Ertmer, 1999, 2005; Ertmer, Addison, Lane, Ross, \& Woods, 1999; Ertmer et al., 2012; Francom, 2016, 2020; Hew \& Brush, 2007). Categorized as first-order and second-order, barriers have been mentioned to explain teachers' infrequent and low-level technology use. First-order barriers, which are external to the teacher, concern obstacles such as a lack of resources, 
lack of technical and institutional support, or lack of training. In contrast, second-order barriers, which are internal to the teacher, have to do with teachers' underlying beliefs about learning and teaching, about technology and about their current classroom practices and their unwillingness to change (Ertmer, 1999). Similar to the categorization of barriers, Ertmer et al. (2006) suggest that enablers can be viewed as being intrinsic and extrinsic to the teacher. For example, the availability of and access to technology and technical and administrative support might be viewed as extrinsic while the factors related to teachers' beliefs and attitudes as intrinsic. They also add that "enablers and barriers may be viewed as having an inverse relationship. That is, as enabling factors increase, barriers are likely to decrease" (p. 55). They conclude that a decrease in barriers or an increase in enablers is likely to lead to greater technology use.

To summarize, a considerable amount of research has been conducted over the past two decades to explore factors that facilitate or impede teachers' technology integration practices in various educational settings. Numerous studies have identified teacher-related factors such as teachers' attitudes and beliefs toward technology integration and school-related factors including technology infrastructure and administrative support as significant predictors of teachers' technology use in education. Considering the efforts to increase technology use in the classroom in various educational settings and the agreed upon critical role teachers play in the implementation of new technologies, it seems more than necessary to understand how teachers perceive factors that are likely to influence their integration practices before mandating any technology use in the classroom (Miranda \& Russel, 2012; Hur et al., 2016). The present study aims to add to the literature by exploring how university level EFL instructors in Turkey perceive the factors that would potentially influence their decisions and practices regarding technology integration.

\subsubsection{Studies Conducted in The Turkish Context}

A number of studies have been conducted in the Turkish context to explore the factors and barriers affecting teachers' use of technology in the classroom. In their earlier study with 326 social studies teachers from primary schools, Gülbahar and Güven (2008) found out that teachers were willing to integrate technology into their classrooms, but they had problems in having an access to technological resources and lacked in-service training opportunities. Şahin-Kızıl (2011) conducted research with 76 high-school EFL teachers to explore their technology use and attitudes toward its integration. Analysis of questionnaire data showed that teachers had positive attitudes toward using technology for educational purposes, but insufficient class time and inadequate training opportunities were the obstacles confronting their technology integration. In their study with 18 social studies teachers working in a primary school, Ünal and Öztürk (2012) explored the barriers experienced by teachers to integrate technology into their teaching. Lack of technological equipment in classrooms, lack of computer-based teaching resources, the effect of traditional teaching approaches on instructional practices, inadequacy of in-service training and insufficiency of time were perceived as the major barriers to adopt technology.

Similarly, Aydın (2013) investigated primary and secondary school Turkish EFL teachers' knowledge of software and personal computer use, attitudes toward and self-confidence in technology integration, and the school climate and support offered to the teachers for the use of technology. Responses of 157 EFL teachers to a survey revealed that teachers had a very limited knowledge of certain software and had difficulties in using them. Despite their positive perceptions of technology integration, lack of technical and instructional support appeared to be potential barriers to their technology integration. Also, Göktaş, Gedik and Baydaş (2013) aimed to reveal barriers experienced by Turkish primary school teachers to utilize technology for instruction. A survey developed by the researchers was applied to 1373 teachers from 52 schools and findings revealed lack of or limitations of hardware, lack of appropriate software materials, lack of in-service training, and lack of technical support as the main barriers encountered. In her qualitative study, Özdemir (2017) aimed to find out the 
barriers experienced by Turkish teachers to integrate technology into their teaching. Fourteen Turkish teachers working in public schools were selected for the study and interviewed. Content analysis of the data obtained from the interview revealed eight major obstacles preventing teachers from technology integration: inadequacy of technology infrastructure of the school, lack of technology for teacher and the students, not directing the program to technology, not being suitable for Turkish lessons, habits, loss of time, and lack of course materials for Turkish lessons.

In short, a review of literature in the Turkish context reveals that factors relating to technology use of primary, secondary and high school teachers of different subject areas have been well documented. However, only few studies have been conducted with EFL instructors in higher education institutions in Turkey. To fulfil this gap in the literature, this study focuses on university level EFL teachers' perceptions of teacher and school related factors that would potentially influence their technology integration practices in the classroom. In the present study, the scope of technology is narrowed down to the computer hardware, software and Internet as these are the key components of the educational environment where the study has taken place. Likewise, integration of technology will refer to the use of computers and related technologies for instructional purposes. In this framework, the current study poses the following research questions to be answered:

1. How do Turkish EFL teachers perceive their knowledge about computer software?

2. What are the personal computer use habits of Turkish EFL teachers?

3. What are the attitudes of Turkish EFL instructors toward using computers for teaching and learning purposes?

4. How do Turkish EFL teachers perceive their self-confidence in integrating computers into their teaching?

5. How do Turkish EFL teachers perceive the school climate and support in relation to the use of computers for instruction?

\section{Method}

\subsection{Setting}

The current research is a case study that adopts a quantitative research design. Researchers selected an English Preparatory Program of a state university in Ankara (Turkey) as the unit of analysis. The goal of this English Preparatory Program (and all university Preparatory Programs, in general, in Turkey) is to offer university students an extensive program so that they can improve their English as a foreign language before they proceed to their departments. Upon their entry to university, students whose English is not sufficient to earn the required scores set by the university are placed in these English Preparatory Programs. In this case, the Preparatory Program of the chosen state university offered two semesters of extensive English instruction, 24 hours a week. At the time of the study, the program had one principal, four coordinators, 70 teachers and 964 students.

The institution had two computer labs with 30 computers in each and 40 regular classrooms with a computer system that reflected the computer screen to a TV set. All computers in the classrooms had Internet connections, with an institutional Internet limiting system installed. So, only the web sites allowed by the administration could be accessed and they were generally limited to educational websites only. Teachers could also access from their classes to all necessary materials that are stored in a common server, but they were not allowed to bring their own laptop computers to the classes. Teachers could either use coursebooks from publishers or prepare their own extra materials and upload to the server prior to the lessons. Computer labs were open to students and teachers during the day when there were no classes. Both teachers and students used the labs only for self-study purposes. Informal observations 
at the institution and talks with the teachers indicated that teachers mostly used technology for instructional preparation and delivery. Computers were mainly seen and used as modern overhead projectors. Technology integration did not involve students' use of technology as a learning tool, for example, to create a product and share with others. Technology integration was a personal choice on the part of the teachers rather than an administrative policy. The impetus for the present study came from the need to understand the factors that are likely to affect teachers' decisions to reject or adopt technology in their teaching. If any further administrative decision was to be made with regard to using computer-based technologies in EFL instruction in more effective ways or establishing a framework to do so in this institution, empirical evidence as to the factors affecting EFL teachers' use of such technologies in instruction were crucial to investigate. This fact proved to be not only a justification as to why researchers opted for this particular group of participants, but it also contributed to the significance of the study from an instructional perspective.

\subsection{Participants}

All the teachers in the Preparatory Program $(\mathrm{N}=70)$ participated in the study. Of all the participants, $19(27.1 \%)$ were male and $51(72.9 \%)$ were female. Fifty-nine participants $(84 \%)$ were novice teachers (0-5 years of experience), six teachers (9\%) had 6-10 years of experience, and five teachers (7\%) had been working for than 11 years. In terms of educational background, $48(68.6 \%)$ teachers had a bachelor's degree or a post-graduate certificate in English Language Teaching (ELT), 15 (21.4\%) teachers continued their master's program, four $(5.7 \%)$ of them had finished their master's, one $(1.4 \%)$ was enrolled in a $\mathrm{PhD}$ program, and two $(2.9 \%)$ of them had already received their doctorate diplomas in the field. Teachers were also the graduates of different departments. That is, 51 (72.9\%) teachers graduated from English Language Teaching department, 15 (21.3\%) from Literature department, two (2.9\%) from Translation and Interpretation department, and two (2.9\%) from Linguistics department. Finally, all participating teachers stated that they took one or two computer courses in their undergraduate programs while 53 of them $(75.7 \%)$ declared that they also received the Technology and Material Development Course offered by the Department of ELT. Stand-alone computer courses aimed to equip pre-service teachers with a set of competences in basic computer applications such as word processors, spreadsheets, databases and presentation programs. Technology and Material Design course, on the other hand, was designed to provide pre-service teachers with the necessary knowledge and skills in using various technologies to design instructional materials.

\subsection{Data Collection Instrument and Procedure}

Data were collected in the 2018-2019 academic year through an instrument developed by Papanastasiou and Angeli (2008) to explore the factors affecting teachers' teaching with technology. The questionnaire consisted of a demographics section and five scales including (1) teachers' knowledge about software, (2) teachers' frequency of software use for personal purposes, (3) teachers' attitudes toward integrating computers in teaching and learning, (4) teachers' self-confidence in using computers for teaching, and (5) school climate and support regarding the use of computers for instruction. The demographics section aimed to gather information about the composition of the sample group as well as some specific information as to their background. The first scale with 14 items aimed to measure teachers' knowledge of various computer software programs. The items were answered on a 5-point Likert scale ranging from "I cannot use it" (1) to "I can use it very well" (5). The second scale was about the frequency of software use for personal purposes. Teachers responded to a 5-point Likert scale ranging from "never" to "almost every day". The third and fourth scales measured teachers' attitudes (15 items) and self-confidence ( 8 items) with a 5-point Likert scale that ranged from "completely disagree" (1) to "completely agree" (5). Finally, the last scale evaluated teachers' perceptions of school 
climate and support with 12 items answered on a 5-point Likert scale that similarly ranged from "completely disagree" (1) to "completely agree" (5). Papanastasiou and Angeli (2008) stressed that the corresponding scales of the questionnaire obtained construct validity as a result of the explanatory factor analysis. They also emphasized that since the questionnaire was divided into distinct sections that were not comparable to each other, and which also had different measurement scales, the factor analysis was performed separately for each section of the questionnaire. Based on this finding, the current research also assumed that the scales as separate parts of the questionnaire (and as factors affecting EFL teachers' use of computer-based technologies in instruction) had construct validity.

The data collection tool was translated into Turkish in order to avoid any misconceptions on the part of the participants and to ensure most accurate answers. The translated questionnaire was given to three field experts for translation and language overview. According to the experts' comments and corrections, necessary changes were made to the Turkish translation of the questionnaire and subsequently printed versions were distributed to the participants. It took nearly three weeks for all the participants to return the questionnaire forms, and the data collection phase was completed in January 2018.

\subsection{Ethical Considerations}

Research ethics were strictly taken into consideration throughout the study. Anonymity of the participants and their workplace were assured so as to reach at sincere responses. After the official permission was granted from the language institution, written consents of the participants were taken through informed consent forms.

\subsection{Data Analysis}

Statistical analyses were conducted using SPSS 21 software program. Descriptive statistics were used in the analysis of the questionnaire data. Frequency counts, mean scores and standard deviations of the participants' responses to the items were calculated for each scale of the questionnaire. The results were analyzed on an item-basis for each part of the questionnaire for each research question separately. The reliability coefficients of each scale were computed in Cronbach's Alpha and the values were respectively as follows: perceived knowledge about computer software $(\alpha=.70)$, personal computer use habits $(\alpha=.65)$, attitudes towards integrating computers into instruction $(\alpha=.84)$, self-confidence in integrating computers into teaching $(\alpha=.70)$, and school climate and support $(\alpha=.86)$. Reliability of two scales, namely attitudes towards integrating computers into instruction and school climate and support, were found high, whereas the reliability values for the other three scales were found satisfactory (Nunnally \& Bernstein, 1994).

\section{Results}

The results are reported in the order of the research questions posed: teachers' perceived knowledge about various software programs, their personal computer use habits, their attitudes toward integrating computers in teaching and learning, their self-confidence in using computers for teaching purposes and their perceptions of school climate and support. This order also reflects the order of the scales in the data collection tool. Therefore, any corresponding data related to the research questions will be reported where necessary. 


\subsection{Perceived Knowledge about Computer Software}

Teachers' responses regarding their perceived knowledge about computer software demonstrated that participants could use certain group of software programs more proficiently than others. Among the programs that teachers could use either very well or well were the Internet with the highest mean score of 4.61, email $(M=4.51)$, presentation software $(M=4.50)$ and word processing $(M=4.28)$. They moderately knew how to use programs such as graphics and spreadsheets $(\mathrm{M}=3.34$ and $\mathrm{M}=3.12$, respectively). On the other hand, their level of perceived knowledge was respectively low when it came to using concept mapping $(M=2.12)$, publishing $(M=1.81)$ and multimedia authoring $(M=1.71)$ software. More than half of the teachers chose the response of 'I cannot use it' for these three programs. Finally, teachers' perceived proficiency was very limited in terms of webpage authoring $(\mathrm{M}=1.47)$, programming languages $(M=1.32)$, microworlds/simulations $(M=1.17)$ and modelling software $(M=$ 1.15). Analysis of the teachers' responses to these specific software programs revealed that the percentages of teachers who could not use the program at all ranged from 67.1 to 88.6. Detailed representation of the teachers' responses is given in Table 1 below.

Table 1. Perceived knowledge about computer software

\begin{tabular}{|c|c|c|c|c|c|c|c|c|}
\hline No & Computer Software & $\begin{array}{c}\text { I } \\
\text { cannot } \\
\text { use it } \\
\%\end{array}$ & $\begin{array}{c}\text { I can use it } \\
\text { to a small } \\
\text { extent } \\
\%\end{array}$ & $\begin{array}{c}\text { I can use it } \\
\text { satisfactorily } \\
\%\end{array}$ & $\begin{array}{c}\text { I can } \\
\text { use it } \\
\text { well } \\
\%\end{array}$ & $\begin{array}{c}\text { I can use } \\
\text { it very } \\
\text { well } \\
\%\end{array}$ & Mean & SD \\
\hline 1 & Word processing & - & - & 8.6 & 54.3 & 37.1 & 4.28 & .61 \\
\hline 2 & Databases & 41.4 & 32.9 & 20.0 & 4.3 & 1.4 & 1.91 & .95 \\
\hline 3 & Spreadsheets & 1.4 & 25.7 & 40.0 & 24.3 & 8.6 & 3.12 & .94 \\
\hline 4 & Graphics & 4.3 & 21.4 & 28.6 & 27.1 & 18.6 & 3.34 & 1.14 \\
\hline 5 & $\begin{array}{l}\text { Multimedia authoring } \\
\text { software }\end{array}$ & 58.6 & 22.9 & 11.4 & 2.9 & 4.3 & 1.71 & 1.06 \\
\hline 6 & Presentation software & - & 1.4 & 5.7 & 34.3 & 58.6 & 4.50 & .67 \\
\hline 7 & Internet & - & - & - & 30.0 & 70.0 & 4.61 & .76 \\
\hline 8 & Concept mapping & 52.9 & 11.4 & 17.1 & 7.1 & 11.4 & 2.12 & 1.42 \\
\hline 9 & Email & 4.3 & - & 2.9 & 25.7 & 67.1 & 4.51 & .91 \\
\hline 10 & Publishing software & 60.0 & 18.6 & 10.0 & 2.9 & 8.6 & 1.81 & 1.25 \\
\hline 11 & $\begin{array}{l}\text { Webpage authoring } \\
\text { software }\end{array}$ & 67.1 & 21.4 & 10.0 & - & 1.4 & 1.47 & .79 \\
\hline 12 & Programming languages & 71.4 & 24.3 & 4.3 & - & - & 1.32 & .55 \\
\hline 13 & Modeling software & 85.7 & 12.9 & 1.4 & - & - & 1.15 & .40 \\
\hline 14 & Microworlds/Simulations & 88.6 & 8.6 & 1.4 & - & 1.4 & 1.17 & .58 \\
\hline
\end{tabular}




\subsection{Personal Computer Use Habits}

As presented in Table 2, the responses of the teachers to the second scale measuring the frequency of software use for personal purposes indicated that teachers used computers, most frequently, to access the Internet $(M=4.84)$, to communicate $(M=4.74)$, to process text $(M=4.47)$ and to make presentations $(\mathrm{M}=4.01)$. More specifically, $91.4 \%$ of the teachers used the computer to access the Internet daily. $75 \%$ used computers to communicate, for example via email, almost every day too. The percentage of the teachers who used the computer to process text most frequently was 57.1. Analysis of the item about using computers to make presentations revealed that almost half of the teachers $(45.7 \%)$ used the computer for this educational purpose once or twice a week while $31.4 \%$ of them used it almost every day. $50 \%$ of the teachers never played a game on the computer. Similarly, almost half of the teachers (41.4\%) never used the computer to publish materials using software such as Publisher. In relation to the use of specialized applications, majority of teachers (ranging from $75.7 \%$ to $97.1 \%$ ) stated that they never created concept maps, developed webpages or multimedia, used microworlds/simulations, modelled complex systems or programmed the computer.

Table 2. Personal computer use habits

\begin{tabular}{|c|c|c|c|c|c|c|c|c|}
\hline No & Item & $\begin{array}{l}\text { Never } \\
\%\end{array}$ & $\begin{array}{c}\text { Once or } \\
\text { twice a } \\
\text { semester } \\
\%\end{array}$ & $\begin{array}{c}\text { Once } \\
\text { or } \\
\text { twice a } \\
\text { month } \\
\%\end{array}$ & $\begin{array}{c}\text { Once or } \\
\text { twice a } \\
\text { week } \\
\%\end{array}$ & $\begin{array}{c}\text { Almost } \\
\text { everyday } \\
\%\end{array}$ & Mean & SD \\
\hline 1 & Play games & 50.0 & 18.6 & 15.7 & 7.1 & 8.6 & 2.05 & 1.31 \\
\hline 2 & Make presentations & - & 7.1 & 15.7 & 45.7 & 31.4 & 4.01 & .87 \\
\hline 3 & Process text & - & 1.4 & 7.1 & 34.3 & 57.1 & 4.47 & .69 \\
\hline 4 & Publish materials & 41.4 & 31.4 & 18.6 & 2.9 & 5.7 & 2.00 & 1.11 \\
\hline 5 & Prepare spreadsheets & 14.3 & 34.3 & 22.9 & 18.6 & 10.0 & 2.75 & 1.20 \\
\hline 6 & Create graphics & 27.1 & 32.9 & 21.4 & 11.4 & 7.1 & 2.38 & 1.20 \\
\hline 7 & Communicate & - & - & 1.4 & 22.9 & 75.7 & 4.74 & .47 \\
\hline 8 & Access the Internet & 1.4 & 1.4 & - & 5.7 & 91.4 & 4.84 & .62 \\
\hline 9 & Develop web pages & 90.0 & 7.1 & - & 2.9 & - & 1.15 & .55 \\
\hline 10 & Develop multimedia & 95.7 & 4.3 & - & - & - & 1.04 & .20 \\
\hline 11 & $\begin{array}{l}\text { Author microworlds / } \\
\text { simulations }\end{array}$ & 95.7 & 1.4 & 2.9 & - & - & 1.07 & .35 \\
\hline 12 & Map concepts & 75.7 & 10.0 & 11.4 & 2.9 & - & 1.41 & .80 \\
\hline 13 & Model complex systems & 97.1 & 2.9 & - & - & - & 1.02 & .16 \\
\hline 14 & Program the computer & 97.1 & 1.4 & 1.4 & - & - & 1.04 & .26 \\
\hline 15 & Use Educational CD & 22.9 & 27.1 & 12.9 & 21.4 & 15.7 & 2.80 & 1.42 \\
\hline
\end{tabular}

\subsection{Attitudes toward Integrating Computers into Instruction}

Results from this part of the survey revealed that teachers generally had very positive attitudes toward using computers for teaching and learning purposes (scale mean score $\mathrm{M}=4.28$ ). They mostly felt comfortable (95.7\%) and excited (90\%) with the idea of using computers in their teaching. Only few 
teachers felt stressed (1.4\%), skeptical (1.4\%), or scared (2.9\%) with the concept. The majority of the teachers $(71,4 \%)$ said they could fix any computer-related problems. A significant proportion of teachers believed that the computers would change the way they taught $(84.3 \%)$ and the way the students learned (87.2\%). They thought that computers not only helped teachers to teach in more effective ways $(94.3 \%)$, but also helped students understand concepts in more effective ways (94.3\%) and learn better (94.3\%). Teachers mostly disagreed with the idea that computers were not beneficial in teaching due to technical difficulties $(87.1 \%)$ or practicality $(95.7 \%)$. Despite general positive attitudes toward computers, $38.6 \%$ of the participants stated that they were still unsure whether or not the computer was a valuable tool for teachers, while slightly over half (52.9\%) agreed on its value with none to strongly agree. Finally, $64.3 \%$ of the participating teachers disagreed that they could do what the computer could do equally as well. Percentages and mean scores of the participant responses to the corresponding attitude items can be found below in Table 3 .

Table 3. Attitudes toward integrating computers into instruction

\begin{tabular}{|c|c|c|c|c|c|c|c|c|}
\hline No & Item & $\begin{array}{c}\text { Strongly } \\
\text { Disagree } \\
\%\end{array}$ & $\begin{array}{c}\text { Disagree } \\
\%\end{array}$ & $\begin{array}{c}\text { Unsure } \\
\%\end{array}$ & $\begin{array}{c}\text { Agree } \\
\%\end{array}$ & $\begin{array}{l}\text { Strongly } \\
\text { Agree } \\
\%\end{array}$ & Mean & SD \\
\hline 1 & $\begin{array}{l}\text { I feel comfortable with the } \\
\text { idea of the computer as a tool } \\
\text { in teaching and learning. }\end{array}$ & - & 2.9 & 1.4 & 37.1 & 58.6 & 4.51 & .67 \\
\hline 2 & $\begin{array}{l}\text { The use of computers in } \\
\text { teaching and learning stresses } \\
\text { me out.* }\end{array}$ & 70.0 & 25.7 & 2.9 & - & 1.4 & 4.62 & .68 \\
\hline 3 & $\begin{array}{l}\text { If something goes wrong I } \\
\text { will not know how to fix it.* }\end{array}$ & 35.7 & 35.7 & 22.9 & 5.7 & - & 4.01 & .90 \\
\hline 4 & $\begin{array}{l}\text { The idea of using a computer } \\
\text { in teaching and learning } \\
\text { makes me skeptical.* }\end{array}$ & 68.6 & 27.1 & 2.9 & 1.4 & - & 4.63 & .61 \\
\hline 5 & $\begin{array}{l}\text { The use of the computer as a } \\
\text { learning tool excites me. }\end{array}$ & 1.4 & 2.9 & 5.7 & 34.3 & 55.7 & 4.40 & .84 \\
\hline 6 & $\begin{array}{l}\text { The use of computers in } \\
\text { teaching and learning scares } \\
\text { me.* }\end{array}$ & 71.4 & 24.3 & 1.4 & 2.9 & - & 4.64 & .66 \\
\hline 7 & $\begin{array}{l}\text { The computer is a valuable } \\
\text { tool for teachers. }\end{array}$ & 2.9 & 5.7 & 38.6 & 52.9 & - & 4.41 & .73 \\
\hline 8 & $\begin{array}{l}\text { The computer will change the } \\
\text { way I teach. }\end{array}$ & 1.4 & 2.9 & 11.4 & 35.7 & 48.6 & 4.27 & .88 \\
\hline 9 & $\begin{array}{l}\text { The computer will change the } \\
\text { way students learn in my } \\
\text { classes. }\end{array}$ & - & - & 12.9 & 38.6 & 48.6 & 4.35 & .70 \\
\hline 10 & $\begin{array}{l}\text { I can do what the computer } \\
\text { can do equally as well. }\end{array}$ & 20.0 & 44.3 & 28.6 & 7.1 & - & 2.22 & .85 \\
\hline 11 & $\begin{array}{l}\text { The computer is not } \\
\text { conducive to student learning } \\
\text { because it is not easy to use.* }\end{array}$ & 70.0 & 25.7 & 1.4 & 1.4 & 1.4 & 4.61 & .72 \\
\hline 12 & $\begin{array}{l}\text { The computer helps students } \\
\text { understand concepts in more } \\
\text { effective ways. }\end{array}$ & 2.9 & - & 2.9 & 50.0 & 44.3 & 4.32 & .79 \\
\hline
\end{tabular}




\begin{tabular}{llccccccc}
\hline No Item & $\begin{array}{c}\text { Strongly } \\
\text { Disagree } \\
\%\end{array}$ & $\begin{array}{c}\text { Disagree } \\
\%\end{array}$ & $\begin{array}{c}\text { Unsure } \\
\%\end{array}$ & $\begin{array}{c}\text { Agree } \\
\%\end{array}$ & $\begin{array}{c}\text { Strongly } \\
\text { Agree } \\
\%\end{array}$ & Mean & SD \\
\hline $\begin{array}{l}\text { The computer helps students } \\
\text { learn because it allows them } \\
\text { to express their thinking in } \\
\text { better and different ways. }\end{array}$ & - & - & 8.6 & 48.6 & 42.9 & 4.34 & .63 \\
$\begin{array}{l}\text { The computer helps teachers } \\
\text { to teach in more effective } \\
\text { ways. }\end{array}$ & 1.4 & - & 4.3 & 41.4 & 52.9 & 4.44 & .71 \\
$\begin{array}{l}\text { The computer is not } \\
\text { conducive to good teaching } \\
\text { because it creates technical } \\
\text { problems.* }\end{array}$ & 57.1 & 30.0 & 10.0 & 2.9 & - & 4.41 & .78 \\
* The items with asterisk are reverse-coded, so their mean scores are computed and reported accordingly.
\end{tabular}

\subsection{Self-Confidence in Integrating Computers into Teaching}

Participants' responses to this group of items indicated high level of self-confidence in integrating computers into their teaching (scale mean score $M=4.07$ ). Majority of the participants said that they felt confident in selecting appropriate software to use in their instruction (72.9\%). Moreover, all participants showed confidence in designing technology-enhanced learning activities for their students $(100 \%)$. Teachers stated that they could confidently use emailing to communicate with students (84.3\%), Internet in their lessons to meet certain learning goals (97.1\%), and PowerPoint (98.6\%) as a presentation tool in the classroom. Nevertheless, participants showed a certain level of hesitancy (with $31.4 \%$ unsure) when it came to teaching their students to select appropriate software to use in their projects. A similar stance was demonstrated by the teachers with nearly half of the participants (45.7\%) not feeling confident in terms of teaching their students how to make their own web pages. Finally, the majority of teachers felt confident that computers could help students understand concepts more easily (97.2\%). Consequently, the results generally revealed teachers' high self-confidence in integrating technology into their instruction. Detailed representation of the participant responses is given in Table 4.

Table 4. Perceived self-confidence in integrating computers into teaching

\begin{tabular}{llccccccc}
\hline No & I feel confident that... & $\begin{array}{c}\text { Strongly } \\
\text { Disagree } \\
\%\end{array}$ & $\begin{array}{c}\text { Disagree } \\
\%\end{array}$ & $\begin{array}{c}\text { Unsure } \\
\%\end{array}$ & $\begin{array}{c}\text { Agree } \\
\%\end{array}$ & $\begin{array}{c}\text { Strongly } \\
\text { Agree } \\
\%\end{array}$ & Mean & SD \\
\hline $\begin{array}{l}\text { I can select appropriate } \\
\text { software to use in my } \\
\text { teaching. }\end{array}$ & 1.4 & 2.9 & 22.9 & 52.9 & 20.0 & 3.87 & .81 \\
$2 \quad \begin{array}{l}\text { I can use PowerPoint in my } \\
\text { class. }\end{array}$ & - & - & 1.4 & 24.3 & 74.3 & 4.72 & .47 \\
$\quad \begin{array}{l}\text { I can design technology- } \\
\text { enhanced learning activities } \\
\text { for my students. }\end{array}$ & - & - & - & 44.3 & 55.7 & 4.55 & .50 \\
$\begin{array}{l}\text { I can use email to } \\
\text { communicate with my } \\
\text { students. }\end{array}$ & 5.7 & 7.1 & 2.9 & 28.6 & 55.7 & 4.21 & 1.16 \\
\hline
\end{tabular}




\begin{tabular}{llccccccc}
\hline No & I feel confident that... & $\begin{array}{c}\text { Strongly } \\
\text { Disagree } \\
\%\end{array}$ & $\begin{array}{c}\text { Disagree } \\
\%\end{array}$ & $\begin{array}{c}\text { Unsure } \\
\%\end{array}$ & $\begin{array}{c}\text { Agree } \\
\%\end{array}$ & $\begin{array}{c}\text { Strongly } \\
\text { Agree } \\
\%\end{array}$ & Mean & SD \\
\hline $\begin{array}{l}\text { I can teach my students to } \\
\text { select appropriate software to } \\
\text { use in their projects. }\end{array}$ & 5.7 & 18.6 & 31.4 & 30.0 & 14.3 & 3.28 & 1.10 \\
$\quad \begin{array}{l}\text { I can teach my students how } \\
\text { to make their own web pages. }\end{array}$ & 14.3 & 31.4 & 18.6 & 22.9 & 12.9 & 2.88 & 1.28 \\
$\quad \begin{array}{l}\text { I can use the Internet in my } \\
\text { lessons to meet certain } \\
\text { learning goals. }\end{array}$ & 1.4 & 1.4 & - & 40.0 & 57.1 & 4.50 & .71 \\
& $\begin{array}{l}\text { The computer can help } \\
\text { students understand concepts } \\
\text { more easily. }\end{array}$ & 1.4 & 1.4 & - & 35.7 & 61.4 & 4.55 & .67 \\
\hline
\end{tabular}

\subsection{School Climate and Support}

The last group of results came from teachers' responses to items related to school climate and support in using technology for educational purposes. According to the results, participants claimed that school climate and support in integrating technology into their instruction was moderate to low (scale mean score $\mathrm{M}=2.95$ ). A more specific item-by-item look at the results showed that participants perceived moderately positive school climate among colleagues, but low support of administration in using technology. $80 \%$ of the participants stated that other teachers used computers in teaching and learning. The same percentage of teachers $(80 \%)$ also said they exchanged ideas about technology integration with other teachers and $62.8 \%$ emphasized that their colleagues encouraged them to integrate computers in teaching and learning. Moreover, $61.5 \%$ of the teachers thought that there was an agreement among colleagues on the value of computers as an instructional tool. However, significant percentage of participants pointed that they were unsure of the administrator support, particularly support from the ICT coordinator $(41.4 \%)$, the principal $(44.3 \%)$ and the inspector $(41.4 \%)$ regarding computer use in teaching while only $22.9 \%$ agreed on ICT coordinator support, only $21.4 \%$ on that of their principal, and $20 \%$ on that of the inspector. This low level of administrational support was similarly reflected in that only $17.2 \%$ of the participants said integrating computer into instruction was never a discussion topic in faculty meetings. Finally, in relation to technology infrastructure, insufficiency and inadequacy of technological facilities and support were reported by the majority of participants. Only $11.4 \%$ of the teachers agreed on the availability of necessary software programs and $22.8 \%$ on the adequacy of technical infrastructure. Similarly, only $28.6 \%$ agreed that technical and instructional support was satisfactory. Detailed information as to the participant responses and their percentages regarding school climate and support are presented below in Table 5.

Table 5. School climate and support

\begin{tabular}{llccccccc}
\hline No Item & $\begin{array}{c}\text { Strongly } \\
\text { Disagree } \\
\%\end{array}$ & $\begin{array}{c}\text { Disagree } \\
\%\end{array}$ & $\begin{array}{c}\text { Unsure } \\
\%\end{array}$ & $\begin{array}{c}\text { Agree } \\
\%\end{array}$ & $\begin{array}{c}\text { Strongly } \\
\text { Agree } \\
\%\end{array}$ & Mean & SD \\
\hline $\begin{array}{l}\text { Other teachers encourage me } \\
\text { to integrate computers in } \\
\text { teaching and learning. }\end{array}$ & 1.4 & 10.0 & 25.7 & 51.4 & 11.4 & 3.61 & .87 \\
\hline
\end{tabular}




\begin{tabular}{|c|c|c|c|c|c|c|c|c|}
\hline No & Item & $\begin{array}{l}\text { Strongly } \\
\text { Disagree } \\
\%\end{array}$ & $\begin{array}{l}\text { Disagree } \\
\%\end{array}$ & $\begin{array}{c}\text { Unsure } \\
\%\end{array}$ & $\begin{array}{c}\text { Agree } \\
\%\end{array}$ & $\begin{array}{l}\text { Strongly } \\
\text { Agree } \\
\%\end{array}$ & Mean & SD \\
\hline 2 & $\begin{array}{l}\text { The ICT coordinator } \\
\text { encourages me to integrate } \\
\text { computers in teaching and } \\
\text { learning. }\end{array}$ & 12.9 & 22.9 & 41.4 & 22.9 & - & 2.74 & .95 \\
\hline 3 & $\begin{array}{l}\text { The principal encourages me } \\
\text { to integrate computers in } \\
\text { teaching and learning. }\end{array}$ & 20.0 & 14.3 & 44.3 & 21.4 & - & 2.67 & 1.03 \\
\hline 4 & $\begin{array}{l}\text { The inspector encourages me } \\
\text { to integrate computers in } \\
\text { teaching and learning. }\end{array}$ & 21.4 & 17.1 & 41.4 & 20.0 & - & 2.60 & 1.04 \\
\hline 5 & $\begin{array}{l}\text { I often exchange ideas about } \\
\text { technology integration with } \\
\text { other teachers. }\end{array}$ & 4.3 & 7.1 & 8.6 & 55.7 & 24.3 & 3.88 & 1.00 \\
\hline 6 & $\begin{array}{l}\text { There are other teachers in } \\
\text { my school who use computers } \\
\text { in teaching and learning. }\end{array}$ & 7.1 & 1.4 & 11.4 & 55.7 & 24.3 & 3.88 & 1.02 \\
\hline 7 & $\begin{array}{l}\text { In faculty meetings. we } \\
\text { frequently discuss the subject } \\
\text { of integrating computers in } \\
\text { the school curriculum. }\end{array}$ & 30.0 & 18.6 & 34.2 & 12.9 & 4.3 & 2.42 & 1.17 \\
\hline 8 & $\begin{array}{l}\text { Teachers in my school are } \\
\text { well informed about the value } \\
\text { of computers in teaching and } \\
\text { learning. }\end{array}$ & 12.9 & 1.4 & 24.3 & 52.9 & 8.6 & 3.42 & 1.11 \\
\hline 9 & $\begin{array}{l}\text { A variety of computer } \\
\text { software is available for use } \\
\text { in my school. }\end{array}$ & 21.4 & 34.3 & 32.9 & 11.4 & - & 2.34 & .94 \\
\hline 10 & $\begin{array}{l}\text { The technical support in my } \\
\text { school is adequate. }\end{array}$ & 18.6 & 31.4 & 21.4 & 28.6 & - & 2.60 & 1.09 \\
\hline 11 & $\begin{array}{l}\text { The instructional support in } \\
\text { my school is adequate. }\end{array}$ & 18.6 & 18.6 & 34.2 & 27.2 & 1.4 & 2.74 & 1.09 \\
\hline 12 & $\begin{array}{l}\text { The technical infrastructure in } \\
\text { my school is adequate. }\end{array}$ & 18.6 & 32.9 & 25.7 & 21.4 & 1.4 & 2.54 & 1.07 \\
\hline
\end{tabular}

\section{Discussion}

The current study aimed at identifying university level EFL teachers' perceived level of knowledge about computer software programs, personal computer-use habits, attitudes toward and self-confidence in integrating computers into teaching and perceptions about school climate and support with respect to computer use. On one hand, results regarding participants' perceived knowledge about and attitudes toward computers have drawn a general outline as to how much they can and choose to use computers in their teaching. On the other hand, results regarding their self-confidence and their schools' climate and support have unveiled possible reasons behind their willingness or reluctance to integrate 
technology in their instruction. The results will be discussed respectively in the order of the research questions posed.

The first research question inquired about teachers' self-reported ability to use computer software programs. According to the results, the participants perceived that they used the Internet and email very well. They also perceived themselves to be mostly proficient in commonly-used programs such as wordprocessing and presentation software. However, teachers' perceived knowledge about using specialized software or special applications was quite low. That is, they had very limited experience in creating concept maps, webpages or multimedia. Majority of them could not create programming languages, use modeling software or implement microworlds/simulations at all. Common use software applications are the ones that are usually taught in basic computer or technology training courses (Papanastasiou \& Angel, 2008). Thus, teachers' higher ability in using the common software can be partly attributed to the computer related courses they had received during their undergraduate studies. People in today's world, including teachers, also commonly use such programs in their daily lives since they are among the most necessary tools to navigate through today's digital world.

In relation to the second research question, teachers' responses to the scale measuring personal computer use habits revealed that they used computers, most frequently, to access to the Internet, to communicate via email, to process text using word processing tools or make presentations. However, their use of specialized software was infrequent or almost nonexistent. They infrequently played games or rarely created webpages, multimedia or concept maps. Teachers' higher perceived knowledge about more frequent use of common software programs and, on the contrary, lower self-reported ability and infrequent or no use of specialized and general-purpose applications support the findings of previous studies (e.g., Aydın, 2013; Usluel, Mumcu, \& Demirarslan, 2007; Somekh, 2008). For example, in Aydın's (2013) study, teachers' technology use was limited to using common software such as the Internet, email, word processing and presentation software. Teachers never or rarely used specialized software programs. Similarly, teachers in the study of Usluel et al. (2007) mostly used word processing and Internet applications in their basic, administrative, and instructional tasks. However, they rarely used databases, graphic and drawing programs.

As well established in the literature, teachers' perceived competency is a strong predictor of their technology integration (e.g., Inan \& Lowther, 2010; Li et al., 2018; Anderson et al., 2011; Sipila, 2014; Hsu, 2010). As Lawrence and Tar (2018) put it, "a teacher that has skill or knowledge is in a better position to judge the usefulness of adopting and integrating ICT into teaching and learning activities" (p. 93). In the present study, teachers' low level of knowledge about and infrequent use of specialized software indicated the need for further training on how to use different technological tools for teaching and learning purposes so that they may adopt such skills into their instruction in the future and thus have more varied technology integration practices.

The third research question focused on the attitudes of university level Turkish EFL instructors toward using computers in their instruction. Similar to the findings in various studies (e.g., Aydin, 2013; Kim \& Keller, 2011; Rogosic, 2015; Lawrence \& Tar, 2018), the participant teachers in the current study generally had very positive attitudes toward using computers for teaching and learning purposes. They not only believed in the value of computers as an instructional tool for teachers, but they also emphasized its significance for learners with many perceived benefits. As another teacher related factor, teacher attitudes have been proven to have an impact on teachers' technology integration decisions and practices (Hew \& Brush, 2007; Lawrence \& Tar, 2018; Salleh, 2016). Teachers with positive attitudes are found to be more willing to integrate technology into their teaching (Hernández-Ramos et al., 2014). In the present study, the teachers' positive attitudes toward integration of technology into their instruction can be interpreted as their tendency and willingness to use computers in their classes. 
The current study concentrated its fourth point of investigation on the teachers' self-confidence in using technology for teaching purposes. Similar to the findings of many other studies (e.g. Aydin, 2013; Hsu, 2010; Lawrence \& Tar, 2018; Rogosic, 2015), this study revealed that university level Turkish EFL teachers, in general, had high level of self-confidence in terms of incorporating technology into their instruction. They especially felt confident using PowerPoint to present, email to communicate, or the Internet to meet their educational goals. However, in relation to the integration of less commonly used software and applications, their self-confidence level was lower, supporting the findings of Aydin (2013) and Rogosic (2015). Teachers' responses also indicated their lack of confidence in teaching students how to make their own pages. Referring to the findings of the first and second research questions, it can be concluded that teachers felt confident in using the technologies that they were familiar with and that they frequently used for personal purposes.

The final point of inquiry aimed to find out teachers' perceptions of school climate and support. Parallel to the findings of similar studies (Aydın, 2013; Rogosic, 2015; Everson \& Prosser, 2019), the present study pointed toward a moderately positive school atmosphere especially among colleagues, but limited support of administration especially in terms of encouragement, technical support and sufficiency of facilities. Contrary to the findings of Aydın (2013) and Rogosic (2015), majority of the teachers in this study perceived that they were not encouraged by the administration to integrate technology. Instead, they agreed on the peer support as an encouraging factor. Peer support has also been mentioned by many other teachers as a facilitating factor in the process of technology integration (Hsu \& Kuan 2013; Karaca, Can, \& Y1ldırım, 2013).

Teachers in the current study also agreed on the unavailability of a variety of computer software, insufficiency of technical infrastructure and inadequacy of technical and instructional support in their working environment. As widely discussed in the relevant literature, lack of technological resources and lack of administrative, technological and training support act as first-order or external barriers to teachers' technology use (e.g., Ertmer, 1999, 2005; Ertmer et al., 1999; Ertmer et al., 2012; Hew \& Brush, 2007; Francom, 2016, 2020). Teachers' adoption of technology depends primarily on the availability and accessibility of technology resources (Lawrence \& Tar, 2018). Therefore, appropriate budgets must be secured to equip the teaching environments with ample technology. However, improving the technological facilities might not always guarantee teachers' effective technology integration (Göktaş et al., 2013). Teachers, as agents of change, should also be provided with training opportunities. In this study, teachers agreed on the inadequacy of instructional support. Perceived lack of training opportunities has similarly been mentioned by teachers in many other studies (Aydın, 2013; Pelgrum, 2001; Toprakç1, 2006; Özden, 2007). In relation to school related factors, it can be concluded that school climate and support as a first-order barrier is a significant issue in this case. Although university level EFL teachers might have positive attitudes and high self-confidence in terms of technology integration, lack of administrational, technical and instructional support may hamper any attempts to use computer in language teaching. Besides, support and encouragement from the colleagues may not be sufficient to overcome such a challenge.

\section{Conclusions}

To summarize, this study aimed to explore factors that might potentially influence technology integration practices of a specific group of EFL teachers working in the Preparatory Language School of a state university in Turkey. Findings revealed teachers' higher perceived knowledge about and more frequent personal use of common technologies. Similarly, teachers felt confident in adopting these technologies for teaching purposes. Opposite results were obtained concerning the more specialized 
technological tools. In general, teachers' attitudes toward integrating computers into teaching were positive. However, teachers showed negative feelings about the administrative, technical and instructional support and the technical infrastructure at their institution. Based on these findings, this study recommends that, for teachers, ample technology needs to be provided, along with administrative and technical support and continuous training specifically designed to address their identified needs in technology use and integration.

Today, as the world goes through a pandemic (COVID-19) period globally, all teachers around the world revisit their knowledge about and skills to use technology in order to carry out their on-line courses. Whether synchronous or asynchronous, and ready or not ready, teachers have started using digital technologies to continue education under this dire and unexpected conditions dictated by the precautions taken against the deadly pandemic. As a result, as homes have become the classroom for both the teachers and the learners, the topic of technology and its integration into instruction will continue to bring significant implications for the future of education as well.

This study has its limitations too. First of all, since this is a case study, the findings are limited to the participant group involved. Further studies are necessary with other university level state school ELT teachers for the generalizability of the results. Secondly, the study is only based on self-perceptions. Perceptions may not always be reflected truly by the participants. Finally, the study has used a quantitative methodology, but future studies might make use of qualitative research designs to have an in-depth understanding of factors affecting teachers' technology use.

\section{Ethics Committee Approval}

The author(s) confirm(s) that the study does not need ethics committee approval according to the research integrity rules in their country (Date of Confirmation: May 12, 2019).

\section{References}

Anderson, S. E., Groulx, J. G., \& Maninger, R. M. (2011). Relationships among preservice teachers' technology-related abilities, beliefs, and intentions to use technology in their future classrooms. Journal of Educational Computing Research, 45(3), 321-338.

Aydın, S. (2013). Teachers' perceptions about the use of computers in EFL teaching and learning: The case of Turkey. Computer Assisted Language Learning, 26(3), 214-233.

Buabeng-Andoh, C. (2012). Factors influencing teachers' adoption and integration of information and communication technology into teaching: A review of the literature. International Journal of Education and Development using ICT, 8(1), 136-155.

Davies, R. S., \& West, R. E. (2014). Technology integration in schools. In M. Spector, M.D. Merrill, J. Elen, \& M.J. Bishop (Eds.) Handbook of research on educational communications and technology (4th ed., pp. 841-853). Springer New York.

Durff, L., \& Carter, M. (2019). Overcoming second-order barriers to technology integration in K-5 schools. Journal of Educational Research and Practice, 9(1), 246-260.

Ertmer, P. A. (1999). Addressing first-and second-order barriers to change: Strategies for technology integration. Educational Technology Research and Development, 47(4), 47-61. 
Ertmer, P. A. (2005). Teacher pedagogical beliefs: The final frontier in our quest for technology integration? Technology Research and Development, 53(4), 25-39.

Ertmer, P. A., \& Ottenbreit-Leftwich, A. T. (2010). Teacher technology change: How knowledge, confidence, beliefs, and culture intersect. Journal of Research on Technology in Education, 42(3), 255-284.

Ertmer, P. A., \& Ottenbreit-Leftwich, A. (2013). Removing obstacles to the pedagogical changes required by Jonassen's vision of authentic technology-enabled learning. Computers \& Education, 64, 175-182.

Ertmer, P. A., Ottenbreit-Leftwich, A., \& York, C. S. (2006). Exemplary technology-using teachers: Perceptions of factors influencing success. Journal of Computing in Teacher Education, 23(2), 5561.

Ertmer, P. A., Ottenbreit-Leftwich, A. T., Sadik, O., Sendurur, E., \& Sendurur, P. (2012). Teacher beliefs and technology integration practices: A critical relationship. Computers \& Education, $59(2), 423-435$.

Ertmer, P. A., Paul, A., Molly, L., Eva, R., \& Denise, W. (1999). Examining teachers' beliefs about the role of technology in the elementary classroom. Journal of Research on Computing in Education, 32(1), 54-72.

Everson, I., \& Prosser, S. K. (2019). Teachers' perceptions of school culture and professional development related to technology. Tennessee Educational Leadership, 46(2), 14-40.

Francom, G. M. (2016). Barriers to technology use in large and small school districts. Journal of Information Technology Education: Research, 15(1), 577-591.

Francom, G. M. (2020). Barriers to technology integration: A time-series survey study. Journal of Research on Technology in Education, 52(1), 1-16.

Göktaş, Y., Gedik, N., \& Baydas, O. (2013). Enablers and barriers to the use of ICT in primary schools in Turkey: A comparative study of 2005-2011. Computers \& Education, 68, 211-222.

Gülbahar, Y., \& Güven, I. (2008). A survey on ICT usage and the perceptions of social studies teachers in Turkey. Journal of Educational Technology \& Society, 11(3), 37-51.

Gürfidan, H., \& Koç, M. (2016). The impact of school culture, technology leadership, and support services on teachers' technology integration: A structural equation modeling. Education \& Science, 41(188), 99-116.

Hermans, R., Tondeur, J., Van Braak, J., \& Valcke, M. (2008). The impact of primary school teachers' educational beliefs on the classroom use of computers. Computers \& Education, 51(4), 1499-1509.

Hernández-Ramos, J. P., Martínez-Abad, F., Peñalvo, F. J. G., García, M. E. H., \& Rodríguez-Conde, M. J. (2014). Teachers' attitude regarding the use of ICT: A factor reliability and validity study. Computers in Human Behaviour, 31, 509-516.

Hew, K. F., \& Brush, T. (2007). Integrating technology into K-12 teaching and learning: Current knowledge gaps and recommendations for future research. Educational Technology Research and Development, 55(3), 223-252.

Hsu, S. (2010). The relationship between teacher's technology integration ability and usage. Journal of Educational Computing Research, 43(3), 309-325. 
Hsu, S., \& Kuan, P. Y. (2013). The impact of multilevel factors on technology integration: The case of Taiwanese grade 1-9 teachers and schools. Educational Technology Research and Development, $61(1), 25-50$.

Hur, J. W., Shannon, D., \& Wolf, S. (2016). An investigation of relationships between internal and external factors affecting technology integration in classrooms. Journal of Digital Learning in Teacher Education, 32(3), 105-114.

Inan, F. A., \& Lowther, D. L. (2010). Factors affecting technology integration in K-12 classrooms: A path model. Educational Technology Research and Development, 58(2), 137-154.

Inan, F. A., Lowther, D. L., Ross, S. M., \& Strahl, D. (2010). Pattern of classroom activities during students' use of computers: Relations between instructional strategies and computer applications. Teaching and Teacher Education, 26(3), 540-546.

Karaca, F., Can, G., \& Yıldırım, S. (2013). A path model for technology integration into elementary school settings in Turkey. Computers \& Education, 68, 353-365.

Kim, C., \& Keller, J. M. (2011). Toward technology integration: The impact of motivational and volitional email messages. Educational Technology Research and Development, 59(1), 91-111.

Koh, J. H. L., \& Chai, C. S. (2014). Teacher clusters and their perceptions of technological pedagogical content knowledge (TPACK) development through ICT lesson design. Computers \& Education, 70, 222-232.

Kurt, S. (2010). Technology use in elementary education in Turkey: A case study. New Horizons in Education, 58(1): 71-83.

Lawrence, J. E., \& Tar, U. A. (2018). Factors that influence teachers' adoption and integration of ICT in teaching/learning process. Educational Media International, 55(1), 79-105.

Li, Y., Garza, V., Keicher, A., \& Popov, V. (2019). Predicting high school teacher use of technology: Pedagogical beliefs, technological beliefs and attitudes, and teacher training. Technology, Knowledge and Learning, 24(3), 501-518.

Light, D., \& Pierson, E. (2013). The impact of school technology infrastructure on teachers' technology integration: A survey in thirteen countries. Ubiquitous Learning: An International Journal, 5(4), 29-40.

Makki, T. W., O'Neal, L. J., Cotten, S. R., \& Rikard, R. V. (2018). When first-order barriers are high: A comparison of second-and third-order barriers to classroom computing integration. Computers \& Education, 120, 90-97.

Miranda. H. P., \& Russell, M. (2012). Understanding factors associated with teacher directed student use of technology in elementary classrooms: A structural equation modelling approach. British Journal of Educational Technology, 43(4), 652-666.

Morrison, G. R., \& Lowther, D. L. (2010). Integrating computer technology into the classroom: Skills for the 21st century (4th ed.). Boston, MA: Pearson Educational.

Murphy, D. T., \& Gunter, G. A. (1997). Technology integration: The importance of administrative support. Education Media International, 34(3), 136-139.

Nunnally, J. C. \& Bernstein, I. H. (1994). Psychometric theory (3rd ed.). NY: McGraw Hill Inc. 
Ottenbreit-Leftwich, A. T., Glazewski, K. D., Newby, T. J., \& Ertmer, P. A. (2010). Teacher value beliefs associated with using technology: Addressing professional and student needs. Computers \& Education, 55(3), 1321-1335.

Özdemir, S. (2017). Teacher views on barriers to the integration of information and communication technologies in Turkish teaching. International Journal of Environmental \& Science Education, 12(3), 505-521.

Özden, M. (2007). Problems with science and technology education in Turkey. Eurasia Journal of Mathematics, Science \& Technology Education, 3(2), 157-161.

Papanastasiou, E. C., \& Angeli, C. (2008). Evaluating the use of ICT in education: Psychometric properties of the survey of factors affecting teachers teaching with technology (SFA-T3). Educational Technology \& Society, 11(1), 69-86.

Pelgrum, W. J. (2001). Obstacles to the integration of ICT in education: Results from a worldwide educational assessment. Computers \& Education, 37, 163-178.

Rogosic, S. (2015). Construct validity of the questionnaire measuring technical and socio psychological factors which affect successful integration of ICT into education. Croatian Journal of Education, 17(4), 983-1007.

Salleh, S. (2016). Examining the influence of teachers' beliefs toward technology integration in classroom. The International Journal of Information and Learning Technology, 33(1), 17-35.

Sang, G., Valcke, M., Van Braak, J., \& Tondeur, J. (2010). Student teachers' thinking processes and ICT integration: Predictors of prospective teaching behaviors with educational technology. Computers \& Education, 54(1), 103-112.

Schiller, J. (2003). Working with ICT perceptions of Australian principals. Journal of Educational Administration, 41(2), 171-185.

Schrum, L., Galizio, L. M., \& Ledesma, P. (2011). Educational leadership and technology integration: An investigation into preparation, experiences, and roles. Journal of School Leadership, 21(2), 241-261.

Sheninger, E. (2019). Digital leadership: Changing paradigms for changing times. Thousand Oaks, CA: Corwin Press.

Sipila, K. (2014). Educational use of information and communications technology: Teachers' perspective. Technology, Pedagogy and Education, 23(2), 225-241.

Somekh, B. (2008). Factors Affecting Teachers' Pedagogical Adoption of ICT. In J. Voogt \& G. Knezek (Eds.), International Handbook of Information Technology in Primary and Secondary Education (Vol 20, pp. 449-460). Springer, Boston, MA.

Şahin-Kızıl, A. (2011, September). EFL teachers' attitudes toward information and communication technologies (ICT). Paper presented at the 5th International Computer \& Instructional Technologies Symposium, Elazığ, Turkey. http://web.firat.edu.tr/icits2011/icits2011ProceedingBook.pdf

Teo, T. (2011). Factors influencing teachers' intention to use technology: Model development and test. Computers \& Education, 57(4), 2432-2440.

Toprakç1, E. (2006). Obstacles at integration of schools into information and communication technologies by taking into consideration the opinions of the teachers and principals of primary and secondary schools in Turkey. Journal of Instructional Science and Technology (e-JIST), 9(1), 1-16. 
Usluel, Y. K., Mumcu, F. K., \& Demiraslan, Y. (2007). Öğrenme-öğretme sürecinde bilgi ve iletişim teknolojileri: Öğretmenlerin entegrasyon süreci ve engelleriyle ilgili görüşleri. Hacettepe Üniversitesi Ĕ̈itim Fakültesi Dergisi, 32(32), 164-178.

Ünal, S., \& Öztürk, I. H. (2012). Barriers to ITC integration into teachers' classroom practices: Lessons from a case study on social studies teachers in Turkey. World Applied Sciences Journal, 18(7), 939-944.

Van Braak, J., Tondeur, J., \& Valcke, M. (2004). Explaining different types of computer use among primary school teachers. European Journal of Psychology of Education, 19(4), 407-422.

Wong, E. M., \& Li, S. C. (2008). Framing ICT implementation in a context of educational change: A multilevel analysis. School Effectiveness and School Improvement, 19(1), 99-120.

\section{Türk İngilizce öğretmenlerinin teknoloji entegrasyonunu etkileyen faktörler}

\section{hakkındaki algılarının incelenmesi: Bir durum çalışması}

\section{$\ddot{O} \mathbf{z}$}

Teknoloji, eğitimin içerisine etkili öğretim yöntemlerle birlikte dahil edildiğinde, eğitim öğretim süreçlerini zenginleştirebilir. Teknolojik gelişmelerin eğitime getirmiş olduğu değişimlerle birlikte, teknolojiyi öğretime entegre etmede öğretmenin kilit rolü önemini daha da artırmıştır. Bu nedenle, öğretmenlerin teknolojiyi derslerine etkili bir şekilde entegre etmelerini etkileyen faktörlerin araştırılması ve incelenmesi önemli hale gelmiştir. Bu durum çalışması, Türkiye'de bir devlet üniversitesinin hazırlık okulunda görev yapan İngilizce öğretmenleriyle gerçekleştirilmiştir. Çalışma öğretmenlerin teknolojiyi derslerinde kullanımlarını etkileyen faktörlere odaklanmış ve özellikle öğretmenlerin bilgisayar yazılımları konusunda becerilerini, kişisel bilgisayar kullanma alı̧̧kanlıklarını, bilgisayar bazlı teknolojileri öğretim süreçlerine entegre etme hususundaki tavır ve özgüvenlerini ve okul kültürü ve desteği konusunda düşünlerini belirlemeyi hedeflemiş̧ir. Anket ile toplanan verilerin analizi göstermiştir ki öğretmenler sıklıkla kullanılan yazılım programlarını iyi bilmektedirler ve kullanmaktadırlar. Ayrıca, bu teknolojilerin öğretimde kullanılması konusunda özgüvenli hissetmektedirler. Ancak, daha özel yazılımların kullanımı konusunda yeterli bilgiye sahip olmadıklarını düşünmektedirler ve bu teknolojilerin öğretime entegrasyonu hususunda özgüvenleri düşüktür. Öğretmenlerin genel olarak teknoloji entegrasyonuna karşı olumlu tavırları belirlenmiştir. Öğretmenler, diğer öğretmenlerden teknoloji kullanımı konusunda destek görürken, yönetim desteği ile okullarındaki teknoloji donanımını, teknik ve eğitimsel desteği yetersiz bulmuşlardır. Bu çalışmanın bulguları teknolojinin ders içi kullanımıyla ilgili bazı öneriler getirmektedir: öğretmenler teknolojik imkanlara erişimleri konusunda desteklenmeli, yönetim tarafindan gerekli eğitimsel ve teknik desteği görmeli ve öğretmenlere özellikle teknoloji ihtiyaçlarına yönelik eğitimler verilmelidir.

Anahtar sözcükler: İngilizce öğretmenleri; algılar; teknoloji entegrasyonu; tutum; özgüven. 


\section{AUTHOR BIODATA}

Dr. Okan Önalan received his B.A. at Hacettepe University, his M.A. at METU, and his PhD at Gazi University in English Language Teaching (ELT). He has offered methodology courses at various universities as a visiting instructor. He continues to publish his academic work in international journals and delivers teacher-training courses, workshops and seminars at different levels.

Dr. Gökçe Kurt is an instructor in the Department of English Language Teaching at Marmara University, Istanbul. She holds BA, MA and PhD degrees in English Language Education. Her research interests include pre-and inservice teacher education and instructional technologies. 